\title{
A Retórica como Modelo Analítico da Racionalidade Instrumental: Aproximações Teóricas e Empíricas*
}

\author{
Raul Francisco Magalhães \\ Diogo Tourino de Sousa
}

\section{INTRODUÇÃO}

\footnotetext{
$\mathrm{O}$
} debate teórico sobre a noção de racionalidade instrumental dos agentes sociais ocupa um lugar central na teoria da ação, principalmente no que toca o entendimento das dimensões da ordem social. A discussão sobre este ponto tem sido polarizada (desde o último quarto do século anterior) por uma dicotomia em que a racionalidade

\footnotetext{
* Este artigo apresenta resultados do andamento da pesquisa A Retórica como Modelo Analítico da Racionalidade Instrumental: Os Usos da Argumentação em Situações de Conflito de Debate, fomentada pelo Programa Institucional de Bolsas de Iniciação Científica - PIBIC/Conselho Nacional de Desenvolvimento Científico e Tecnológico $\mathrm{CNPq}$ /Universidade Federal de Juiz de Fora - UFJF, que consiste em desdobramentos de certos aspectos da tese de Doutorado em ciência política Racionalidade e Retórica: Teoria Discursiva da Ação Coletiva, defendida no IUPERJ em 2000. O projeto (CNPq 470879/01 NV), por sua vez, insere-se em uma pesquisa maior, As Interações de Fala em Situações de Conflito, coordenada pela lingüista profa. dra. Sônia Bittencourt Silveira, que também coordena o núcleo de pesquisa Interações de Fala: Questões Teóricas e Empíricas, da UFJF, ao qual esses trabalhos estão vinculados. O objetivo deste núcleo é gerar pesquisas que integrem conhecimentos das áreas de lingüística e ciências sociais. Uma versão anterior do artigo foi apresentada no GT de teoria social do XXVI Encontro Anual da Associação Nacional de Pós-Graduação e Pesquisa em Ciências Sociais - ANPOCS, em outubro de 2002. Gostaríamos de agradecer as considerações críticas dos pareceristas anônimos da Dados e assumimos inteira responsabilidade pelo texto final.
}

DADOS - Revista de Ciências Sociais, Rio de Janeiro, Vol. 47, n³ 3, 2004, pp. 577 a 614. 
é imaginada, de um lado, como capacidade de processamento de dados para deliberações ${ }^{1} \mathrm{e}$, em outra vertente, como consenso construído intersubjetivamente, o que implica inclusive na crítica à instrumentalidade como dimensão definidora da razão dos atores ${ }^{2}$. Sínteses teóricas entre os dois campos já foram elaboradas (Reis, 1984), mas o caminho que se apresenta aqui enfatiza a idéia de que existe, no acervo da teoria política, uma forma específica de pensar a racionalidade instrumental como movimento recíproco de linguagens persuasivas. A idéia de instrumentalidade da razão - como condição analítica descritiva, criticamente distante do modelo de cálculo computacional/subjetivo, a partir dos ganhos metodológicos do paradigma da linguagem - leva-nos inevitavelmente, afastando-nos também de qualquer consenso comunicativo nos termos habermasianos, a postular o campo da argumentação como o lugar de reflexão para uma teoria da ação. Em outros termos, trabalharemos as possibilidades de uma teoria lingüística da racionalidade instrumental fundada, portanto, em bases intersubjetivas, mas que não desfoca os elementos intencionais e estratégicos da razão. Mais claramente: estabelecemos, como programa de pesquisa para a teoria da ação, remontar um conceito de retórica. É preciso deixar claro ainda que a presente investigação deseja reconstruir positivamente um conceito de razão instrumental, porém considera que as formulações da escolha racional, baseadas na noção de calculabilidade subjetiva do ator, são inadequadas, tanto na dimensão descritiva da ação racional quanto nos seus aspectos normativos. Consideramos efetivo o avanço teórico do paradigma da linguagem ao tratar a racionalidade como construção intersubjetiva, descentrada do cálculo individual, mas também que o plano da instrumentalidade é crucial à idéia de razão e, portanto, irá apontar no campo da linguagem o espaço de constituição da razão instrumental, e este é o campo retórico, no qual o sentido da persuasão, para além dos objetivos estratégicos do formulador do discurso, depende da interação entre oradores e auditórios, enquanto posições intercambiáveis, e considerados ambos como pólos ativos: a recepção de discursos não é menos retórica que sua enunciação.

A racionalidade dos agentes no mundo social estrutura-se pela retórica, ou seja, o raciocínio opera com discursos persuasivos para si e para os interlocutores - como veremos na formulação seminal de Aristóteles. Uma proposição dessa natureza, em que pese as amplas possibilidades teóricas de argumentar a seu favor, tem que - necessa- 
riamente - ser capaz de equacionar a compreensão de contextos empíricos de ação social. Dessa forma, buscamos registros de algumas situações sociais nas quais fosse possível postular que ali se encontravam agentes racionais, que estes agiam de acordo com o que seriam os seus fins e possuíam como principal meio de realização dos seus objetivos o uso da palavra. Trataremos aqui de dois contextos ilustrativos de ordem e conflito: no primeiro, em torno de um problema econômico, usaremos passagens de uma acareação entre um reclamante, um reclamado e os mediadores do Procon da cidade de Juiz de Fora $\mathrm{MG}^{3}$. No segundo contexto, apresentaremos trechos de debates televisivos entre os candidatos à presidência da República, na campanha para as eleições de 2002, evidentemente interessados em persuadir o eleitorado e sendo obrigados - pela estrutura normativa do debate político - a se valerem unicamente de argumentos para sustentar suas posições e desclassificar os adversários. Quanto à estrutura normativa à qual nos referimos, ela deve ser pensada primeiramente quanto às regras que, no contexto da interação, obrigam à reciprocidade de turnos entre os atores e que limitam ao discurso todos os elementos manipuláveis pelos agentes para alcançar a persuasão. A legitimidade do uso estratégico da fala só existe se nenhum meio extralingüístico de coação se faz presente. Cabe também enfatizar que normas gerais de comportamento social e a estrutura legal da sociedade estão minimamente presentes como aspectos fundacionais de qualquer ação que se pretenda intersubjetiva. A referência que fazemos à ordem normativa ficará mais clara na análise do material empírico.

Interessam-nos três pontos profundamente interligados: o primeiro é analisar os discursos como procedimentos de construção da racionalidade dos agentes interagindo em contextos de conflito. Nos casos em questão, a caracterização do sentido visado pelo agente, que Weber (1991) estabelecia como meta explicativa da teoria da ação racional, é um passo metodológico operado a partir da avaliação dos seus proferimentos retóricos. O segundo ponto toca um lugar polêmico de debate na teoria social contemporânea relativo à dualidade entre ação, potencialmente atômica e criativa, e suas inevitáveis conformações pelas estruturas normativas que, pretendem alguns, dirigem os cursos de ação. Aqui também o plano do discurso é essencial para essa reflexão; neste, parece-nos possível perceber, a um só tempo, a moldagem das retóricas a determinados parâmetros normativos, e a instrumentalização destes como argumentos para legitimar uma posição de 
força. O terceiro refere-se à tentativa de aplicar modelos analíticos que traçam a possibilidade de representação pictórica da operação racional, por meio da esquematização de componentes lógicos ou mais exatamente, quase-lógicos - os chamados entimemas elementares dos argumentos reais jogados pelos agentes em suas interações.

O formato deste texto parte de um ponto de teoria sobre retórica e estrutura semilógica dos argumentos ${ }^{4}$; apresenta analiticamente o material empírico com o qual o modelo pode ser ilustrado; e finaliza com algumas implicações sumárias para o debate acerca das relações entre racionalidade e linguagem.

\section{O RACIOCÍNIO COMO ARGUMENTAÇÃO}

Aristóteles foi o responsável por encontrar um espaço para a retórica - que não era pacífico entre os pensadores do seu tempo -, definindo-a como um saber prático (thecné) necessário às questões públicas. Tais questões provocavam conflitos de opiniões sobre "o que fazer", gerados pela própria dinâmica institucional de uma democracia forma de governo em que um grande grupo de "não-especialistas" tem voz e peso decisório (Aristóteles, 1988; Barilli, 1985; Reboul, 1998, Rohden, 1997). Será o filósofo também que considerará respeitável o uso da palavra apenas para agradar ou mortificar os ouvintes, figurando com esse os valores responsáveis pelos sentimentos comuns da pólis. No livro primeiro dos Tópicos, ele estabelece uma identidade básica entre racionalidade e linguagem, ao definir o raciocínio - a operação da razão - como argumentação: "O raciocínio éum argumento em que, estabelecidas certas coisas, outras coisas se deduzem necessariamente das primeiras" (Aristóteles, 1978:5, ênfases dos autores).

Raciocinar é extrair conclusões de proposições estabelecidas pela linguagem. Na variação de tais proposições (e das formas de subtrair conclusões), diferentes formas de raciocínio aparecerão, criando o espectro das possibilidades da própria razão. O filósofo definiu quatro tipos de raciocínio: a demonstração (parte de premissas verdadeiras e é exclusiva da lógica); a dialética (parte de premissas prováveis); os raciocínios erísticos (partem de premissas aparentemente verdadeiras, mas que não o são); e os raciocínios paralógicos (que partem de premissas falsas). As duas últimas formas são eminentemente sofísticas e apontam para um problema fértil em Aristóteles: a aparência do verdadeiro é matéria para a operação da razão e - de certa forma - necessária à 
argumentação na assembléia, podendo levar a conclusões aceitáveis para os interlocutores, como se fossem raciocínios "legítimos". A semelhança apenas aparente entre os signos e os objetos permite a fala lógica, mas também a fala paralógica como aponta Aristóteles: "[...] além disso, a falácia provém da semelhança entre duas coisas distintas e a semelhança provém da linguagem". (idem:165)

Não é preciso aceitar todo o sistema aristotélico para perceber o ponto capital colocado pelo filósofo, e que é continuamente retomado pelo debate contemporâneo entre razão e linguagem. O espaço da razão (o mundo dos argumentos) cria realidades existentes apenas na linguagem, pois esta pode produzir semelhanças entre coisas distintas e coisas realmente semelhantes. Esse é o primeiro ponto a ser obrigatoriamente retomado: a aparência lógica, operar logicamente sobre premissas falsas ou duvidosas (Boudon, 1990), é um procedimento do mundo da ação. A outra noção fundamental para o momento é o caráter dado nos Tópicos ao raciocínio pelo exemplo, ou seja, a indução. Embora por "raciocínio" Aristóteles costume designar sempre a operação dedutiva, ele também usa o termo para uma forma específica de argumentação, que parte de observações particulares para afirmações universais. Em razão dos problemas lógicos básicos da indução, que os gregos já conheciam muito bem, o filósofo não crê que o recurso ao "exemplo" seja convincente em um debate entre pessoas esclarecidas, mas certamente funciona bem com a multidão (pela sua clareza) que apela diretamente aos sentidos dos interlocutores. A partir da generalização retórica dos casos singulares, a argumentação colhe exemplos e atribui a eles semelhanças e regularidades, extraindo daí proposições gerais que se pretendam válidas.

Questões diferentes, conforme seus públicos, exigirão padrões de argumentação específicos para resolver tal ou qual problema. Os lugares (topoi, tópicos), isto é, as formas pré-estruturadas de fala - pacotes de argumentos convenientes a tipos distintos de temas e estratégias formam um dos elementos-chave da retórica (Perelman e Olbrechts-Tyteca, 1996; Perelman, 1997; Osakabe, 1979; Meyer, 1998; 1994; Peçanha,1989; Boudon, 1989). Ao usar um topos, o agente põe em movimento seqüências de idéias estandardizadas e previamente organizadas para a discussão sobre um tema. Os lugares são programas de argumentação imprescindíveis à organização do pensamento e da compreensão do discurso. A idéia de "lugar-comum" refere-se, originalmente, a um topos que estrutura todos os tipos de discurso in- 
dependentemente da temática: a repetição e a recapitulação são lugares-comuns fundamentais, como também o é o uso da suposição. Exemplos de lugares-comuns a todos os discursos científicos são o repertoriar de opiniões e teorias sobre um assunto antes de dizer o próprio ponto de vista, ou fazer uso de uma suposição para sustentar uma idéia. Aqui será suficiente lembrar que os lugares são obrigatórios na fala, ou seja, principalmente em situações de debate, o raciocínio opera o enquadramento dos fatos dentro de um padrão de argumentação. Esse enquadramento é um limite necessário à persuasão na medida em que define, simultaneamente, o que está em causa e como é possível agir sobre o objeto com um conjunto particular de pensamentos feitos por palavras.

Devemos sintetizar também que a organização persuasiva dos tópicos obedece a requerimentos de natureza moral (o ethos), relativos à adequação e confiabilidade dos valores do agente requerimentos de natureza emocional (pathos) responsáveis pela comunhão de paixões entre orador e audiência, fundamentais para mover a ação; e requerimentos de natureza analítica (o logos) que respondem pela coerência do discurso (Aristóteles, 1988). O modelo retórico aqui usado distingue, a partir daí, quatro modos de organizar a retórica (Magalhães, 2000) $)^{5}$ : o modo deliberativo, no qual se projetam cenários do futuro, mundo possíveis, para orientar uma decisão; o modo judiciário ao reconstruir-se cenários do passado também para motivar uma decisão; o modo epidíctico no qual a persuasão se assenta no elogio ou na vituperação e usa todos os recursos estéticos disponíveis para amplificar os argumentos; e o quarto modo é o analítico, caracterizado pela incorporação de tópicos típicos dos discursos acadêmicos técnicos ou científicos e que busca dar explicações sobre os fatos. Evidentemente, estes quatro modos se entrelaçam em condições reais do uso da fala e é tarefa analítica discriminá-los a fim de tentar estabelecer um sentido de ação para o seu uso em um contexto. É preciso lembrar também que, embora usemos a dicotomia clássica orador/auditório para designar ator e intelocutor, partimos da mesma premissa que orientava Aristóteles, ou seja, a retórica não é apenas uma forma de gerar um discurso, mas também de recebê-lo (a audiência é ativa). A retórica, como toda reflexão sobre linguagem que se preze, parte do princípio de que estamos diante de um processo de contínuo aprimoramento das condições de intersubjetividade dos sentidos racionais dos atores e os coloca em relações normalmente assimétricas, mas não fixas. Essa 
perspectiva nos afasta das especulações sobre uma racionalidade centrada na consciência, ou mente, individual.

Vamos lembrar que o reconhecimento, ou desafio, feito por um agente das estruturas normativas que organizam os contextos de ação, deve ser pensado como o recurso a tópicos discursivos reconstruídos nos contextos de interação. Pretendemos explorar, nos dados empíricos, a relação entre estratégia retórica e uso instrumental da estrutura normativa, no sentido de sua reconstrução no ato interativo. Essencialmente, como costuma ser recorrente em abordagens interativas da ordem social (Schutz, 1974; Schutz e Luckmann, 1977), não estamos pressupondo qualquer existência ontológica de estruturas sociais, mas, ao contrário, indicando primeiramente que a operatividade destas especialmente em casos de conflito, é dependente de suas reelaborações contextuais e da intencionalidade dos agentes em campo. Em segundo lugar, queremos indicar - para os contextos analisados - que a ordem normativa é, necessariamente, um tópico discursivo invocado por um ou mais agentes no campo da ação e, nesse sentido, é um recurso de persuasão retoricamente constituído.

\section{O DESENHO DO ARGUMENTO}

As proposições sinteticamente abordadas no momento anterior indicam a possibilidade de tratarmos teoricamente a racionalidade das ações por meio de conceitos originários da analítica do uso persuasivo da linguagem, e também de investigarmos como a retórica é o procedimento de edificação, uso e modificação dos parâmetros normativos da ordem social. Resta-nos delinear os caminhos da faceta mais ambiciosa da presente investigação, ligados à tentativa de aplicar e aperfeiçoar modelos de descrição pictórica, ou figurativa ${ }^{6}$, da operação do raciocínio retórico. Desde já, é preciso lembrar que estamos no horizonte não de ilustrar operações lógicas formais, mas de compreender esquematicamente as partículas que compõem a lógica mundana dos agentes em interação.

A esse respeito, a base é dada pelos trabalhos de Stephen Toulmin (1997; 1994), que investigam o caráter quase-lógico dos argumentos. Uma qualidade do seu trabalho consiste em se aproximar, exatamente, da idéia de uma validade contextual dos argumentos para, então, discutir sua estrutura invariante (independente de contextos). Assim, ele trabalha, inicialmente, um conceito de campo como o lugar em que 
argumentos são validados. Os campos são áreas de saber nas quais a argumentação se coloca: um campo jurídico, outro da lógica, da mecânica, da religião, da crítica de arte, do futebol e de todas as áreas segmentárias, relativamente móveis, conforme as necessidades do problema posto. De tal forma, os problemas de validade são dados no interior dos campos, e não em uma estrutura que existe para todos os campos. No entanto, ele discute se existe algum padrão estrutural entre os argumentos de campos distintos, portanto independentemente da validade.

Objetivamente, esse filósofo wittgensteiniano propõe que, para todos os casos, argumentos são compostos, ou seja, desenvolvem-se por estágios, os quais conhecidos na lógica como premissas e conclusão, são conectados entre si por termos modais ou qualificadores modais. A modulação é dada pelo uso de palavras como "necessariamente", "possivelmente", "devem", "podem", "com certeza", "sem dúvida", ou qualquer outra que dê os parâmetros para a validade da conclusão do argumento. $O$ modelo tem um estágio chamado "problema", unido a uma "conclusão/solução" por meio de um qualificador modal. Na proposição: 1) "o time A pode ganhar o campeonato", temos um problema implícito no campo de argumentação: o time $A$ joga um campeonato com outros times (problema); o time $A$ pode ganhar dos outros times e levar o campeonato (conclusão ou solução). O qualificador modal "pode" indica que o resultado é possível, provável, mas não necessário; a construção 2) "o time A vai ganhar o campeonato" tem exatamente o mesmo problema e a mesma solução, mas o qualificador "vai" significa "necessariamen$t e^{\prime \prime}$. Isso leva o debate sobre a validade desse argumento para uma direção distinta da primeira formulação. Toulmin estabelece aí alguns elementos importantes: a argumentação é um processo em estágios, cuja aceitação começa a ser definida pela modulação empregada e pelas suas conseqüências em termos dos critérios demandados para avaliar sua validade no campo em que se colocou. Argumentos são referidos ao campo (field-dependent) e qualquer debate sobre a validade substantiva de um argumento é, doravante, vinculado ao campo em que esse argumento é enunciado.

Toulmin pretendeu ir além e colocou o problema de encontrar algo que a tradição da filosofia analítica, à qual ele pertence, chama de invariante (ou constante lógica dos argumentos), ou seja, aquela estrutura mínima que pode, como um modelo de operação lógica, habitar distintos topos, distintos campos de validade. Ele pensa, então, um 
plano estrutural (lay-out) do argumento que possa ser usado não só intracampos, mas intercampos. Essa imagem estrutural do argumento não foi elaborada com base em uma pesquisa empírica, mas por meio de exemplos verossimeis, que tinham a tarefa de delinear o modelo toulminiano do raciocínio argumentativo. Assim, raciocinamos a partir de fatos (datum) " $F$ " e deles chegamos a conclusões ou proposições (claims) " $\mathrm{P}$ ". O modelo é bipolar, pois, dados os fatos, resultam proposições. Temos o clássico $F \rightarrow$ então, $P$ (se F, então, $P$ ); ou,"se nuvens negras, então, chuva", "se time fraco, então, derrota", "se dinheiro, então, compras" e todas as demais relações pensáveis que um conjunto de fatos sustenta. No uso comum das proposições, as pessoas partem dos fatos para as asserções, mas há sempre a possibilidade de desafios ao que está sendo dito. De tal forma que o modelo se $F$, então, $P$ pode ser aprimorado introduzindo-se algum tipo de garantia ou justificação "J" (warrant) distinto tanto dos fatos quanto das proposições. Então, obtém-se: "nuvens negras se acumulam no horizonte" $(F)$, dado que "o acúmulo de nuvens negras traz chuva" $(J)$, então, "vai chover" $(P)$; o modelo desenha

Figura 1

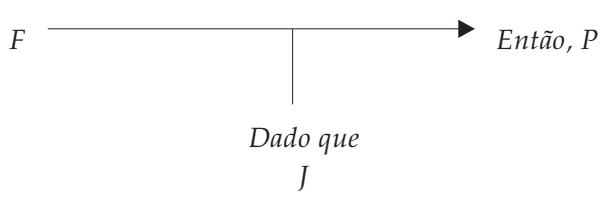

É preciso distinguir, claramente, o papel dos fatos e das justificativas, uma vez que os primeiros são sempre explícitos para deduzir-se deles as proposições, e os segundos, normalmente, podem ficar implícitos. Mesmo com a justificativa $J$, não decorre que um time por estar fraco perderá necessariamente, daí a operação "se $F$, então, $P$ " é inadmissível. $\mathrm{O}$ argumento, nesse caso, para tornar-se próximo do campo da validade, requer um qualificador modal " $Q$ " para alterar o seu critério de avaliação em direção a uma proposição mais verossímil:

Figura 2

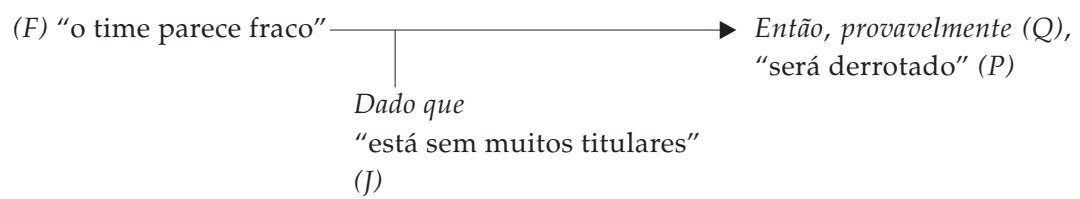


Essa configuração ainda é sujeita a controvérsias, pois "provavelmente" é um qualificador modal, que deixa em aberto a probabilidade da asserção $P$ ("será derrotado") não ser válida para traduzir todos os arranjos possíveis dos fatos; há, logicamente, a possibilidade de o time vencer, apesar das dificuldades. O filósofo considera que o qualificador modal tem, por conseguinte, de supor uma refutação, ou réplica " $R$ " (rebuttal), de tal maneira que:

Figura 3

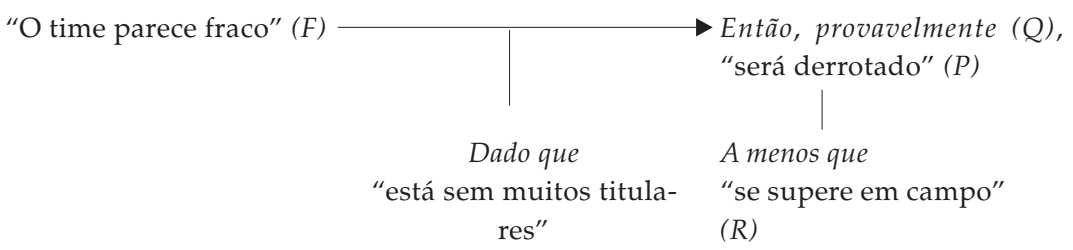

(J)

O qualificador modal $Q$ indica que: se uma possibilidade na realidade existe, também há possibilidade de o contrário ocorrer de fato; ou se um desafio ao argumento por um interlocutor que considera a justificativa J insuficiente. Isso lança, para a configuração do argumento, a necessidade de prever as condições de sua própria refutação. $\mathrm{Na}$ defesa de uma pretensão ou asserção, os agentes produzem dados por meio de enquadramentos dos fatos e os usam, conforme a necessidade de explicitar suas justificativas, para sustentar uma conclusão, geralmente possível naquelas condições. O desafio à proposição, ou asserção, é com certeza um desafio extensivo às suas justificativas, por exemplo: "por que inferir que o time está fraco baseado na ausência daqueles titulares?". Isso leva, com certeza, à necessidade de respaldar a justificativa básica. Qualquer fato invocado como justificativa tem de se fundamentar também em outras fontes de autoridade, estas sim, só explicitáveis em um processo de debate. "Aqueles titulares são os responsáveis por 95\% dos gols marcados" - esta pode ser uma resposta ao desafio sobre a falta dos titulares no time justificar tanto o enquadramento do time como fraco quanto a conclusão de que ele será provavelmente derrotado (a menos que se supere em campo). Para o filósofo analítico, tal resposta - que só seria acionada em condições especiais, pois, do contrário, a proposição seria aceita - constitui-se sua sustentação "S" (backing), de forma a dar essa figuração ao modelo: 
Figura 4

"o time parece fraco" $(F)$

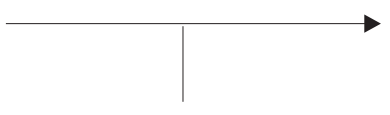

Dado que "está sem muitos titulares"

(J)

Considerando-se que

"aqueles são os titulares que marcam os gols"

(S)

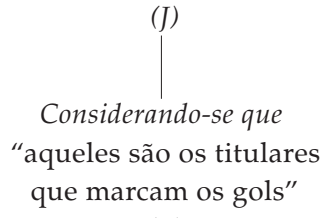

$(S)$
Então, provavelmente $(Q)$,

"será derrotado" $(P)$

A menos que "se supere em campo"

(R)

Mais esquematicamente:

Figura 5

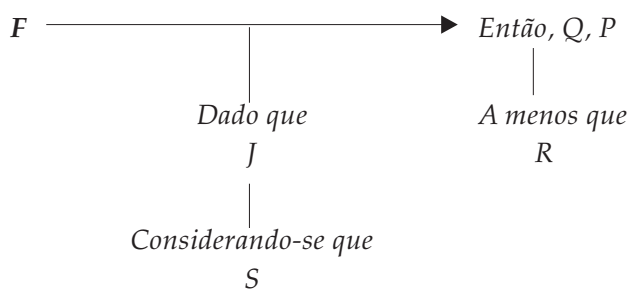

Os argumentos, nas conversações, vão sendo usados, e sua validade, se resolvida pelos agentes sem desafios, consiste apenas na operação correta da sua figura lógica: se $F \rightarrow P$.

No entanto, se há necessidade de ajustes e de debates quanto à validade, o argumento deve ser capaz de sustentar-se em diferentes graus de saber referidos ao campo. Tais backings são operações discursivas internas ao campo no qual o argumento está posto. Em uma conversa sobre moral ou estética, enquanto os interlocutores estiverem concordando com tudo o que é dito, interagem apenas exigindo a forma lógica dados / conclusões (se $A$, então, $B$ ), para continuarem se "entendendo". Porém, se houver alguma discordância de conteúdo sobre moral ou estética, os interlocutores terão de acionar a autoridade de suas justificativas e sustentações, pois a lógica, por si só, não resolve um debate dessa natureza. Validar os lugares usados como justificativas e sustentações é tarefa da argumentação, portanto da retórica. Quanto 
mais avança o debate, mais os argumentos se tornam referidos ao campo de validade, embora o modelo lógico subjacente permaneça o mesmo. Os termos modais, se explícitos no discurso cotidiano, transformam modelos do tipo "todos os As são Bs" ou "nenhum Aé B" em modulações como "quase todos os As são Bs" ou "dificilmente um Aé B". Porém, as modulações podem ficar implícitas, e o plausível "quase todo A é B" transforma-se em um categórico e "lógico", "[quase] todo A é $B^{\prime \prime}$, aceito normalmente, dado que é sempre possível, se desafiado o argumento, explicitar as condições de sua modulação. Assim, o modelo usado na argumentação dentro de campos de validade não definidos a priori, mas supostos a priori, como na vida comum, é o que Toulmin chama, no mesmo espírito de Perelman, de quase-silogismo. A idéia de uma estruturação quase-lógica necessária à compreensão e ao debate de um argumento tem óbvias conseqüências para o problema da persuasão. Uma aparência lógica é condição para um silogismo passar de uma possibilidade de verdade à sua aceitação como verdadeiro (válido e virtualmente persuasivo).

Os quase-silogismos - ou entimemas - têm, precisamente, a aparência do silogismo enquanto tal por desenhá-lo logicamente dentro de um campo no qual ele é possivelmente aceito se sua forma puder acessar os conhecimentos supostos (backings) que garantem as suas proposições. O modelo de Toulmin é consistente com alguns aspectos, tanto nas teorias da racionalidade instrumental quanto no debate da retórica propriamente dito. Outro ponto central no modelo discutido refere-se à existência de um jogo intersubjetivo não explicitado em todos os argumentos, ou só explicitado em debate. A cada fala, novos grupos de fatos que podem sustentar os discursos têm de ficar supostos na relação entre um universo não enunciado, maior que qualquer fala posta pelos agentes. De tal forma, alguns elementos do discurso podem - no movimento contrário ao do silogismo clássico - tornar-se implícitos, criando entimemas que articulam rapidamente o formato fatos / proposições. A idéia de um campo composto por lugares de argumentação é uma conseqüência do próprio conceito de retórica - uma vez que a noção de uma garantia de validade só poderia se dar pelo uso de novos fatos no debate, que dependem de padrões de argumentação.

Desse modo, a forma quase-lógica guarda, a um só instante, uma identidade aparente com a constante lógica elementar e dela se distancia por ser também a figuração não exata do mundo. Trata-se da 
identidade e da diferença entre "Todo A é B" e "Todo A, (possivelmente) $e ́ B^{\prime \prime}$. Propomos, então, identificar o modelo quase-silogístico de Toulmin como a constante que estrutura a lógica da retórica, considerando-se os tipos já estabelecidos de discurso persuasivo. Trabalha-se aqui com a proposição de que a análise de tais mecanismos argumentativos é indicadora de estratégias, não meramente discursivas, mas constitutivas das operações da racionalidade instrumental dos agentes que delas lançam mão para seus movimentos no campo da ação.

O primeiro movimento retórico é o enquadramento dos fatos. Essa é uma peça de disputa entre interlocutores e está suposto, tanto para o orador quanto para o auditório, que os fatos poderiam ser outros, mas são aqueles porque somente eles permitem a conclusão deliberativa ou judiciária à qual se quer chegar. Assim, para explicitar a correlação entre fatos retoricamente enquadrados e a conclusão, no lugar do esquema $F \rightarrow$ então, $C$ será preciso grafar em vez de " $F$ ", " $E f^{\prime \prime}$ (enquadramento dos fatos). Um outro aspecto essencial para se chegar a um plano esquemático do argumento, na retórica, liga-se às condições de uso da fala na relação orador/auditório. O discurso deve ser pensado não só como um processo que configura a forma "se $P$, então, $B$ ", mas como uma cadeia: "se $P$, então, $B$, então $C$, então, $D,[\ldots]$ ". Obviamente essa cadeia deve ser pensada levando-se em conta que cada um dos elos implica um jogo de ocultamento e explicitação de garantias, justificativas e refutações.

Assim, para o modo deliberativo, tem-se um enquadramento dos fatos implicando uma projeção do futuro que equivale, no esquema, à conclusão $C$ - aqui renomeada $P f$ (projeção do futuro). De maneira que $E f$ $\rightarrow$, então, Pf. Quanto aos outros elementos do esquema, estes permanecem os mesmos, pois do enquadramento, dos fatos para a projeção, o discurso usará, longamente, garantias e justificativas para fundamentar sua conclusão/ projeção. Da mesma forma o qualificador, normalmente no caso do uso retórico, é substituído por conexões mais enfáticas, o que apenas reforça o caráter quase-lógico da construção. Em vez do analítico, "possivelmente", opta-se pelo uso enfático "com certeza". A refutação pode ser eclipsada ao máximo e matizada com outros argumentos. Contudo, ela compõe as condições de "validade" da fala, o que supõe a possibilidade de ela ser manipulada para reforçar a persuasão. Uma projeção do futuro é uma forma de argumentar que leva o mundo possível a se tornar, uma vez aceito, ele próprio um 
"datum" (fato) do qual nova inferência é exeqüível, levando à decisão " $D$ " e/ou à ação " $A$ ". Assim temos o encadeamento do modo deliberativo com a seguinte configuração:

$E F \rightarrow$, então, $[Q], P f \rightarrow$, então, $D$ e/ou $A$

O modulador $[Q]$ fica entre colchetes, indicando que seu uso é suposto e pode ser explicitado em condições de discussão sobre o critério de validade do discurso. Oculto, ele amplia sua força persuasiva na medida em que, aparentemente, aproxima uma formulação provável de uma formulação necessária. Não aparecem, no esquema anterior, as conexões de backing e a refutação que dão ao lay-out o seguinte desenho lógico:

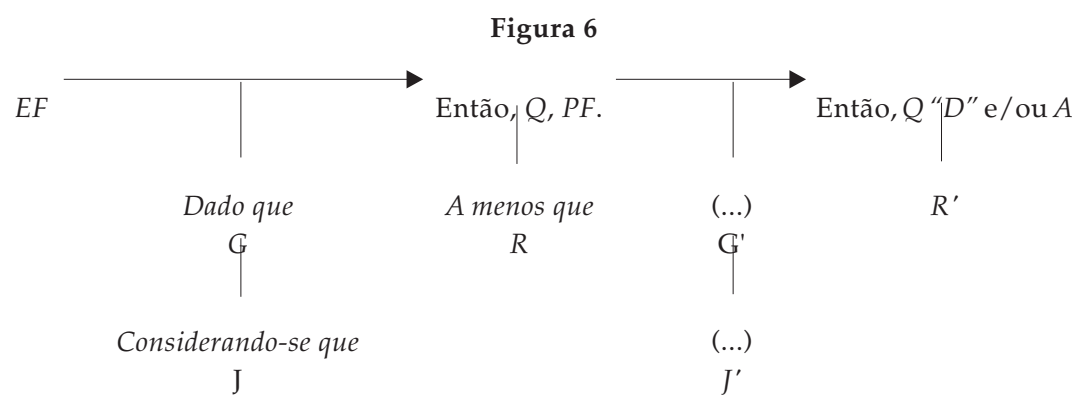

Podemos imaginar:

Figura 7

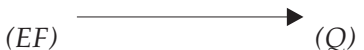

"Nosso maior problema é a seca"
Então, [prov.] "construiremos um açude"

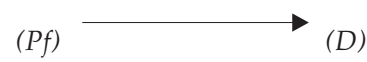

então,[prov.]"pediremos mais verbas públicas"

Os fatos das garantias e sustentações, e mesmo refutações, podem ser retoricamente explicitados ou eclipsados, conforme as conveniências da argumentação que salta de enquadramentos a projeções, tomando-as como dados para saltar em direção a conclusões. Seguindo tal esquema, basta substituir $P f$ ( projeção do futuro) por $R p$ (reconstrução do passado) que está feito o encadeamento elementar do modo Judiciário:

$E F \rightarrow$ então, [Q], representative $\rightarrow$ então, [Q] D ou $A$ 
Quanto ao modo analítico, seu modelo corresponde ao esquema de Toulmin, posto que tal forma retórica se pretende a explicação dos fatos. Devemos sublinhar que qualquer dos pontos do argumento deve apresentar uma estrutura semelhante. Se fosse possível a esquematizar, ela projetaria uma seqüência de silogismos encadeados que podem ser, ou não, explicitados conforme a conveniência do debate.

Mesmo uma proposição estritamente epidíctica (como o elogio fúnebre, ou a vituperação) só pode ser entendida como uma expressão retórica baseada na mais pura pretensão lógica, ou melhor, tautológica: louva-se o louvável; critica-se o criticável. A é b: o político X é ladrão, o líder Y é honrado. Em uma exortação de combate do tipo "todos os que forem brasileiros sigam-me", há uma série de identidades entre ser brasileiro e ligações implícitas entre amar a pátria e seguir o comandante no assalto contra o inimigo. Sem negar a importância do pathos e da eloqüência exigidos pela enunciação eficaz dessa frase, o presente trabalho pretende focar a importância de operações, aqui chamadas quase-lógicas na produção da persuasão, neste e em todos os modos da retórica.

\section{ALGUMA EMPIRIA}

Como já foi mencionado, tomaremos inicialmente os trechos de uma audiência de conciliação do Procon de Juiz de Fora. Essas acareações nas quais reclamantes, reclamados e mediadores da instituição se empenham, tratando de problemas sobre compra, venda, garantias e toda gama de dissenso, que resultam na insatisfação das relações de mercado - fornecem alguns dos dados básicos de pesquisa. Os dados empíricos levantados até o momento apontam para situações nas quais os agentes são confrontados com interesses conflitantes e precisam de persuadir um mediador do Procon, incluindo seu oponente, a se alinharem, ou aceitarem em termos, o seu enquadramento dos fatos. As disputas em torno das versões sobre os fatos que propiciam o conflito revelam estratégias de fala amplamente eivadas de todos os elementos de indignação moral e, evidentemente, de certas modalidades de argumentação quase-lógica. O mediador também não é isento de interesses e tenta estabelecer algum grau de consenso entre as partes. Ele é o representante de um poderoso aparato normativo, o Código de Defesa do Consumidor, que será convenientemente realçado, omitido ou interpretado com o objetivo de propiciar os acordos. $\mathrm{O}$ material das acareações nos traz agentes racionais reais procurando 
atingir seus objetivos, constrangidos pela situação na qual somente a manipulação da linguagem pode configurar um mundo possível (Ronen, 1994; Lewis, 1986; Magalhães, 1997), adequado aos interesses de uma das partes, ou de ambas, nas aparentemente raras situações de acordo. É importante notar que a Lei de Defesa do Consumidor é sempre invocada como uma possibilidade discursivamente construída na fala do mediador. Tentamos realçar os momentos nos quais o corpo normativo que envolve as acareações é, dentro de limites, negociável pelos atores em jogo para que entendimentos sejam possíveis.

O modelo de retórica dominante no caso das acareações é de caráter judiciário, em que os agentes tentam fazer a reconstrução persuasiva mais eficaz de cada caso, com vistas à obtenção de um acordo mais favorável. O grande objetivo dos atores é normalmente controlar o centro do debate (Rapoport, 1980), impondo um tópico de discussão cujo recurso básico de convencimento é a repetição do seu argumento, sempre que possível; também, freqüentemente, usa-se a estratégia de desautorizar a versão do outro, quer por meio de nova versão, quer por meio de escárnios emitidos quando a palavra está com o oponente (o que não é autorizado). O mediador participa como uma força moderadora que se coloca a serviço do acordo quando este pode ocorrer. As invocações do corpo normativo são normalmente na direção de constranger o reclamado a um acordo com o reclamante, e, eventualmente, alertar o reclamante dos limites dos seus direitos. Como ilustração, note-se o seguinte trecho que inicia a versão de um reclamado sobre um caso de carro usado. Sejam (Exemplo 1):

“Rdo reclamado; Rte reclamante (1 e 2) e Med mediador (1 e 2): [...]

Rdo.: Comprô. Olhou a Uno levou a Uno no mecânico. Voltou dizendo que a Uno tinha um defeito ... mandamo arrumar ... ele passou o final de semana com o carro. ... Nu nu nu Domingo, na na nu nu Sábado, num sei na segunda-feira, ele ligou dizendo que não queria o carro. Então tudo bem.

Rte 1.: [Não, tá errado]

Rdo.: Deixa eu contar a história, aí depois cê fala.

Rte 1.: [Não, tá errado. Ham! Tá errado]

Med 1.: [Deixa, deixa ele depois ... passa a palavra pra você. Não, pera aí]. 
Rdo.: [Depois cê fala, senão no nós vamos começar discutir nós dois e não vai ter nada]

Rte 1.: [(Então tá) já começou errado].

Rdo.: Aí ... ele falô que não queria ficar com o carro. Aí el falou assim: então eu vou escolher outro carro. (Então) cê fica a vontade. Escolheu um Gol, levou o Gol pro mecânico dele. O mecânico reprovou o carro, ele voltou ... aí ele escolheu um Monza. ... levou o Monza no mecânico. O Monza tá tudo certo? Tá. Serve prá você? Serve. Ficou com o Monza. ... Levou o Monza. No dia que: ... no no, depois no Sábado o Monza apareceu um defeito, quebrou a: um uma balança lá ... ele ainda me ligou, ainda mandaram arrumar a balança. Agora, depois de 3 meses ou 2 meses que tem que ele me comprô o carro ele me trouxe essa reclamação ... dizendo que tem algumas coisas que foi gasta algumas coisas no carro, agora o que foi gasto no carro, eu nem sei o quê que é, eu nem vi ...

Med 1.: Hum, hum.

Rdo.: Ele tá alegando óleo, filtro e é vela, essas coisas tem que ser feitas ... quem compra um carro usado ..."

Nota-se, no trecho acima, uma versão do passado - típica do modo Judiciário - sendo construída e as intervenções não autorizadas do reclamante para pontuar que este não concordava com a fala do reclamado. A estrutura normativa do ambiente da acareação faz-se claramente observável nas indicações que coordenam a troca de turno (Zimmerman e Boden, 1991; Schegloff, 1996): a primeira levantada pelo reclamado, ciente dos seus direitos de apresentar sua versão do caso ("Deixa eu contar a história, aí depois cê fala.") e, logo em seguida, a segunda levantada pela mediadora que precisava coibir as reclamações em voz alta do outro agente ("Deixa, deixa ele depois ... passa a palavra pra você. Não, pera aí." ). O desafio à ordem, sintetizada no princípio geral que diz que cada interlocutor deve dar chance ao outro de se manifestar, a parece na recusa ao silêncio absoluto do reclamado durante a versão do reclamante. O fato é que, autorizado ou não, a parentemente movido pelo pathos e por uma definição bem mais frouxa da situação, ele faz-se ouvir no debate como desaprovador do discurso em pauta por meio de uma série de intervenções.

Se aplicarmos agora o modelo de figuração dos modos retóricos presumindo alguns bakings plausíveis, teremos para o argumento do reclamado o seguinte modelo: 
Figura 8

$E F \rightarrow$ então,[Q], Rpa $\rightarrow$ então,[Q] D ou $A$

"o mecânico dele avaliou alguns carros e aprovou o Monza" (EF)

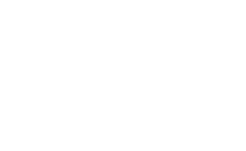

Dado que

"se houvesse

defeito o

mecânico

falaria"

(J)

Considerando-se que

"defeitos de carro são evidentes para um mecânico"

(S)

\section{Figura 9}

“o carro estava em ordem" $(R p)$

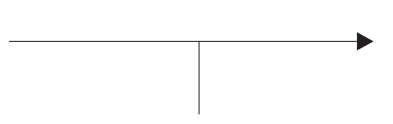

Dado que

"nenhum defeito foi visto na hora da compra"

(J)

Considerando-se que

"quem compra carro usado deve saber o que

faz"
Então, [provavelmente] (Q), “o carro estava em ordem" $(R p)$

A menos que "se prove o contrário"

$(R)$

(S)

A autoridade da opinião do mecânico foi transformada circunstancialmente e retoricamente em princípio normativo gerado no costume da compra e venda de carros usados para fundamentar uma posição de interesse econômico. A acareação segue com a versão do reclamado alegando que o carro apresentou defeitos demais, e que, por isso, ele teria direito a determinadas reparações etc. Um momento importante nesse encontro, que pode ser observado no Exemplo 2, foi a ameaça do uso da lei para constranger o acordo: 
"Med 2.: [Eu::, e a::, e a nota fiscal do carro? Cadê ela? = Rte $1 .:=\mathrm{Nu}$, nu nu me deram Rdo.: ( ) / / o carro é de terceiro ( ) / / = [risos do Rte 1]

Med 2.: = (Mas tem que ter) uma nota de venda, ué.

Rte 1.: [Mas tem que ter tudo, uê.

Med 2.: Tem que ter uma nota de venda, ué.. .. (Quer dizer que) cê é isento de, de, de pagar imposto?

Rdo. : Hm, hum. (Do carro) é. (Vou falá pra). A senhora não me conhece, sabe onde é, o problema do carro ( ) meu estacionamento, meu estacionamento ... meu estacionamento

Med 2.:[Tá, mais, se você tem uma concessionária você tem que, cê tem que emitir uma nota.

Rte 1.: Aham!

Med 2.: Então cê num tem uma, uma loja de vender carro =

Rte 1.: = Então ele num pode vendê carro, né. ... Porque um estacionamento é um estacionamento, ele num pode vendê carro.

(Pausa de 38 segundos - Med.: está analisando as notas de orçamento de peças)

Med 2.: “Tecnocarro é (por conta) do vendedor, né. A loja e - 1001 veículos é estacionamento?

Rdo.: É estacionamento.

Med 2.: (Mas) você vende carro lá dentro?

Rdo.: Vende, / carro também/. Porque lá pode fazê tudo.... O contrato social ( ).

Med 2.: Então não é só estacionamento?. .. É uma concessionária de vender carro.

Rdo.: [Não é só estacionamento. Pode vendê também, isso que eu tô falando $=$

Med 2.: = Vão ter que emitir nota fiscal dos carros que você vendê = Rdo.: = Algumas coisas.

Med 2.: Por que algumas?

Rdo.: Porque esse carro é de terceiro, isso num é meu.

Med 2.: A::, cê vai me desculpar, mas tem alguma coisa errada aí, né.

Rte 1.: Aqui

Med 2.: Se você vendeu lá dentro do seu:: do, da, do, da sua loja, ... no seu contrato social está como vendedor de carro, cê vai me desculpar mas cê tem que dá uma nota fiscal.

(Pausa de 24 segundos)

Med 2.: O quê que nós vamos fazer aí pra resolver isso. É: Lucas? 
(Pausa de 17 segundos)

Rdo.: Xô vê. Oh! Essa bomba aqui eu pago toda. Pronto, pra num ter conversa, pra num ter (...)

A ameaça de fiscalização é uma invocação da ordem normativa que levou o reclamado a mudar de postura e direção a um sinal de cooperação (a disposição de pagar a bomba). É importante dizer que - em um momento seguinte, ao perceber que no desenrolar da sessão a ameaça da fiscalização não era efetiva - o reclamado voltou a endurecer sua posição e o acordo saiu mais conforme o seu interesse, uma vez que a mediadora, após intenso debate, aceitou a tese da aprovação do carro pelo mecânico. Fica claro no trecho que o reclamante, ao perceber a ameaça de fiscalização, reforça a posição do Procon (Med 2.: = Mas tem que ter uma nota de venda, ué. / Rte 1.: Mas tem que ter tudo, $u \hat{e}$.$) . Evidentemente essa é uma manobra que pode lhe render um$ acordo favorável. Quanto ao reclamado, após uma pausa diante da ameaça, decide examinar a nota e negociar uma bomba. Esse é um recuo tático fundamental para aliviar a pressão do Procon.

Outro contexto de interação retórica é fornecido pela situação de debate político eleitoral na televisão, que é regulado por normas preestabelecidas e acordadas entre as partes. A principal ação possível, e a única permitida, expressa-se pelo uso da fala cronometrada. Artifícios retóricos devem levar em consideração possíveis punições previstas no regulamento do debate que basicamente podem dar ao adversário mais tempo em direitos de resposta, ou a ter a própria palavra cassada. A audiência é complexa, sendo formada pelos interlocutores presentes na interação - o auditório de assessores e convidados - e pelos eleitores telespectadores. Aqui, por razões técnicas e analíticas, falaremos apenas das interações entre os interlocutores. $\mathrm{O}$ controle que o mediador exerce sobre os debatedores pode mostrar-se um lastro considerável para a vigência ou não da estrutura normativa e para a capacidade de contestá-la.

O primeiro debate entre os candidatos à presidência da República deu-se em 4 de agosto de 2002, organizado pela rede de televisão Bandeirantes. Foram convidados os quatro principais candidatos, que se encontravam mais bem colocados nas pesquisas. Eram eles: Luiz Inácio Lula da Silva, Ciro Gomes, José Serra e Anthony Garotinho. Está- 
vamos a dois meses da realização das eleições no primeiro turno e os candidatos encontravam-se nas pesquisas da seguinte forma: Lula liderava com vantagem; Ciro encontrava-se em segundo, com uma boa vantagem sobre Serra, o terceiro; e Garotinho vinha em quarto ${ }^{7}$. A mediadora foi a jornalista Márcia Peltier. Os candidatos estavam dispostos da esquerda para a direita: Serra, Lula, Garotinho e Ciro separados por uma considerável distância e com microfones isolados.

O ponto interessante nesse tópico é a discussão sobre o modo como as regras dos debates eram explicitadas. Neste debate, a mediadora, após fazer a apresentação e atribuir os créditos da realização do encontro, chama um narrador que, em off, explica as regras. Desse modo, a estrutura normativa figura um plano exterior aos atores em debate (Exemplo 3).

Márcia Boa noite! A Rede Bandeirantes de televisão e o canal Band News,
cumprindo a sua tradição no compromisso de servir a democracia,
dão início neste momento ao primeiro debate entre os candidatos à
presidência da República [...]. Este debate será formado por seis blocos, que
seguirão as seguintes regras (entra em off explicação das regras por um
narrador).

A possibilidade de questionamento da estrutura normativa é dificultada para os participantes, pois - nos momentos de acirramento dos conflitos - o pedido de direito de resposta, que seria concedido em situações de ofensa pessoal, é julgado e concedido pela organização do debate, tendo a mediadora apenas o papel de comunicar o resultado, que lhe é passado por um aparelho (um ponto). Os julgadores da ordem estão fora do controle dos agentes. Este aspecto configura importante controle da situação. Dessa forma, a unidade elementar da ordem em interação, que é a troca de turno entre os debatedores, fica sob controle, amortecendo o conflito (Exemplo 4):

José Serra (pergunta)
Candidato Ciro Gomes, em entrevistas à CBN e ao Correio Brasiliense, foi afirmado, o sr. afirmou que o valor, abro aspas, "o salário-mínimo em meu governo não pode ficar abaixo de 100 dólares, nenhum dia, custe o que custar, pois foi isso que pagamos quando fui ministro da Fazenda em 1994". À taxa de câmbio de hoje isso significaria um gasto público Federal mínimo de 18 bilhões de reais por ano. De onde vai tirar esse dinheiro? 


\begin{tabular}{|c|c|}
\hline Márcia & Candidato Ciro Gomes, o sr. tem 2 min. para resposta. \\
\hline $\begin{array}{l}\text { Ciro Gomes } \\
\text { (resposta) }\end{array}$ & $\begin{array}{l}\text { Bom, primeiro é preciso datar a afirmativa, porque o sr. sabe eu sou } \\
\text { uma pessoa muito séria e muito responsável, e a taxa de câmbio hoje é } \\
\text { uma conseqüência louca do profundo desequilíbrio que o governo ao } \\
\text { que o sr. serviu por oito anos produziu no país, e evidentemente não } \\
\text { dá para acompanhar e nem eu estou propondo indexar ou vincular } \\
\text { ou corrigir o salário-mínimo diariamente por uma taxa volátil de } \\
\text { câmbio. Quando eu fui ministro da Fazenda, o câmbio estava ao re- } \\
\text { dor de ponto } 85 \text { reais por dólar, e isso equivalia absolutamente a nú- } \\
\text { meros e números redondos aos } 100 \text { dólares, que eu imagino que pode } \\
\text { ser produzido, porque o país naquela data cresceu, teve superávit fis- } \\
\text { cal de } 5 \% \text { do PIB, o desemprego despencou a } 4 \% \text { e as contas da Previ- } \\
\text { dência tiveram superávit. O problema era o conflito distributivo, a } \\
\text { qual senhor você quer servir. Esse ano o governo brasileiro estará } \\
\text { passando } 107 \text { bilhões de reais entre amortizações e juros para uma dí- } \\
\text { vida interna que, quando eu era ministro, era de } 61 \text { bilhões de reais, } \\
\text { equivalente a } 23 \% \text { do PIB e que hoje ascende a } 750 \text { bilhões de reais, em } \\
\text { sete anos, quando o funcionalismo ficou arrochado, oito anos, quan- } \\
\text { do os tributos foram aumentados de } 27 \text { para } 34,5 \% \text { do PIB. Trata-se, } \\
\text { portanto, de saber a que senhor se quer servir, e no meu caso eu quero } \\
\text { ver se sirvo às maiorias populares brasileiras, que precisam que o seu } \\
\text { salário possa suportar o custo de vida que volta a crescer. }\end{array}$ \\
\hline Márcia & Candidato José Serra o sr. tem 1 min. para a réplica. \\
\hline $\begin{array}{l}\text { Serra } \\
\text { (réplica) }\end{array}$ & $\begin{array}{l}\text { E além das maiorias eu quero também servir à verdade, o que o candi- } \\
\text { dato Ciro Gomes disse não é verdade! Quando ele foi ministro da Fa- } \\
\text { zenda por } 116 \text { dias, o salário-mínimo foi de } 82 \text { dólares na média da- } \\
\text { queles meses em que ele foi ministro, o cálculo aqui tá acessível a todo } \\
\text { mundo, não foi } 100 \text { dólares; segundo lugar tanto não foi que a Folha de } \\
\text { São Paulo publicou a seguinte matéria: Ciro Gomes descartou a hipó- } \\
\text { tese do salário-mínimo subir para } 100 \text { dólares (matéria de } 12 / 11 \text { / } 94 \text {. } \\
\text { Descartou a hipótese do salário-mínimo ir para } 100 \text { dólares, entre as- } \\
\text { pas, não é possível fazer isso, diz o Ciro, por causa do impacto que a } \\
\text { medida teria para a Previdência Social e administração pública esta- } \\
\text { dual a municipal. Não só não pagou como disse que não poderia pa- } \\
\text { gar, e não nos disse agora de onde tiraria os } 18 \text { bilhões, ou até se o } \\
\text { câmbio caísse, digamos para } 250,9 \text { bilhões, isso tão pouco foi esclare- } \\
\text { cido, e eu acho importante servir além das massas à verdade. }\end{array}$ \\
\hline Márcia & Ciro, o sr. tem $1 \mathrm{~min}$. para a sua tréplica. \\
\hline $\begin{array}{l}\text { Ciro } \\
\text { (tréplica) }\end{array}$ & $\begin{array}{l}\text { Eu costumo servir à verdade como profissão de fé e de vida, não há } \\
\text { precedente na minha vida pública, já extensa, nem de grosseria, nem } \\
\text { de agressividade, nem de faltar com a verdade... }\end{array}$ \\
\hline Márcia & Eu peço a platéia que por favor se contenha. \\
\hline
\end{tabular}


Ciro (continuação da tréplica)

Essa é a forma com que os auxiliares do sr. José Serra se comportam.

Mas, como eu lhe disse, eu costumo ter e é uma vida extensa, já fui ministro da Fazenda, já fui governador de estado, já fui prefeito da $5^{\underline{a}}$ maior cidade brasileira, fui deputado por dois mandatos e já fui candidato a presidente do Brasil. Não há precedente de incoerência na minha vida. Eu fui ministro de 7 de setembro de 94 a 31 de dezembro de 94, e todo o Brasil sabe que a data de reajuste do salário-mínimo é maio, portanto eu não podia ser cobrado por reajuste e é por essa razão que eu afirmei, porque a data de reajuste é anual e é a data maio, e eu fui ministro da fazenda do começo de setembro, naquela fase crítica de implantação do real quando caiu o Ricúpero, a dezembro de 94. Cobrar de mim isso e deixar de comparar o câmbio da data para fazer falácia com XXX falando em média de 116 dias não é senão expressão de desonestidade intelectual.

\begin{tabular}{ll}
\hline Márcia & Candidato o seu tempo já se esgotou, e agora... \\
Serra & $\begin{array}{l}\text { (inaudível - reclamação sobre a fala de Ciro Gomes, com reivindica- } \\
\text { ção de direito de resposta) }\end{array}$ \\
\hline Márcia & $\begin{array}{l}\text { Tá certo, o sr. tem direito a essa resposta. O candidato tem 1 min. e } \\
\text { meio como direito de resposta. }\end{array}$ \\
\hline Serra & Olha, a questão é a seguinte: o candidato Ciro Gomes afirmou, o Bra- \\
(direito de & sil inteiro leu, ouviu, né, ou escutou, ele disse que pagou quando ele \\
resposta & foi ministro o salário-mínimo era 100 dólares, não tem firula econô- \\
concedido) & mica, eu sou economista, sou professor tive grande experiência em \\
& $\begin{array}{l}\text { economia, e eu acho o seguinte: a gente saber economia é muito im- } \\
\text { portante pra não ser enganado a respeito de informações econômicas }\end{array}$ \\
& no mínimo. Aqui é o seguinte, ele diz: “o valor do salário-mínimo em \\
& meu governo não pode ficar abaixo de 100 dólares nem um dia, o fu- \\
turo governo dele se ele ganhar, custe o que custar, pois foi isso que & pagamos quando fui ministro da Fazenda em 1994". Não foi assim, \\
em setembro o salário-mínimo foi, em dólares, foi de 80,9, em outu- \\
bro 82,7, em novembro 83,16, em dezembro 82,3, eu tirei a média dos \\
quatro meses, ou seja, ele faltou com a verdade quando disse que ti- \\
nha pago um salário-mínimo de 100 dólares, se fosse um comporta- \\
mento isolado vá lá, mas isso tem acontecido inclusive quando disse \\
que pagou a dívida do Ceará mobiliária toda e não pagou, ela aumen- \\
tou 68\% no período, quando disse que foi fundador do meu partido, \\
do PSDB, e não foi ele que entrou no PSDB mais de um ano depois, e \\
por aí vai. E eu acho que o compromisso com a verdade é fundamen- \\
tal...
\end{tabular}

O crescente conflito entre os candidatos Serra e Ciro Gomes resultou em um vitupério, "desonestidade intelectual", que motivou um direito de resposta prontamente administrado pela mediadora. A questão 
de Serra era absolutamente coerente com a eficaz linha de sua campanha eleitoral, que consistia em desacreditar moralmente Ciro Gomes, seu maior competidor pela vaga no segundo turno. Algo como "Ciro mente quando fala de economia", então, é possível completar o entimema, "[provavelmente] mente sobre tudo, então não pode ser presidente". Os componentes da retórica analítica, presentes nos pacotes argumentativos sobre economia lançados pelos dois lados, são muito importantes para autorizar uma disputa por uma definição moral: quem é o mentiroso técnico e político? A jornalista Márcia Peltier faz referência constante à produção do programa como juíza dos conflitos, o que a exime diretamente de contestação. O não-atendimento da reclamação do candidato Ciro Gomes e o restabelecimento da ordem são fortemente marcados: "São as regras candidato".

Esquematicamente, temos o argumento de Serra adicionando a ele algumas sustentações plausíveis:

Figura 10

\begin{tabular}{|c|c|c|c|}
\hline $\begin{array}{l}\text { O candidato Ciro } \longrightarrow \\
\text { Gomes faltou } \\
\text { publicamente } \\
\text { com a verdade } \\
\text { sobre o } \\
\text { salário-mínimo } \\
\text { de } 100 \text { dólares }\end{array}$ & $\begin{array}{l}\text { "então, } \\
{[\text { com }} \\
\text { certeza], }\end{array}$ & $\begin{array}{l}\text { Não pode } \\
\text { ser } \\
\text { Presidente }\end{array}$ & $\begin{array}{l}\text { Então, [com } \\
\text { certeza] } \\
\text { vocês não } \\
\text { podem } \\
\text { votar nele" }\end{array}$ \\
\hline $\begin{array}{l}\text { Dado que } \\
\text { Os cálculos } \\
\text { mostram um } \\
\text { valor inferior a } \\
100 \text { dólares }\end{array}$ & $\begin{array}{l}\text { A menos } \\
\text { que } \\
\text { "Vocês } \\
\text { confiem em } \\
\text { alguém que } \\
\text { mente" }\end{array}$ & $\begin{array}{l}\text { Dado que } \\
\text { Ciro mentiu e mentirá } \\
\text { novamente }\end{array}$ & $\begin{array}{l}\text { A menos } \\
\text { que } \\
\text { "Vocês } \\
\text { queiram ser } \\
\text { enganados" }\end{array}$ \\
\hline $\begin{array}{l}\text { Considerando-se que } \\
\text { eu sou economista, fiz os } \\
\text { cálculos e sei que ele está } \\
\text { mentindo }\end{array}$ & $\begin{array}{r}\text { Cor } \\
\text { também } \mathrm{m} \\
\text { pago a dí } \\
\text { quando } \mathrm{d}\end{array}$ & $\begin{array}{l}\text { siderando-se que } \\
\text { entiu ao dizer que havia } \\
\text { vida do Ceará e mentiu } \\
\text { sse que fundou o PSDB }\end{array}$ & \\
\hline
\end{tabular}

O entimema acima joga uma possível conclusão sobre não se eleger um mentiroso contumaz para a Presidência como uma operação intersubjetiva implícita no argumento usado entre Serra e seu auditório. Ele reconstrói, como um técnico, o passado para acusar Ciro (modo judiciário) de um problema moral (modo epidíctico), visando, 
ao fim, a uma deliberação no futuro. Pode-se também ver com facilidade, no sentido da ação de Serra, a presunção de uma cadeia do tipo Se não Ciro então Serra, para os votos "não Lula" de Ciro. A eficácia dessa estratégia rendeu a Serra um lugar no segundo turno derrubando a candidatura de Ciro Gomes.

Realçar as relações entre ordem e ação parece-nos central na investigação dos fundamentos da interação, como já frisamos no trecho da audiência do Procon. No exato momento em que qualquer regra se afrouxa, temos o espaço para um jogo estratégico mais claramente centrado no ator. Vejamos passagens do segundo debate, ainda no primeiro turno, que ocorreu em 2 de setembro de 2002, e foi organizado pela rede de televisão Record. Também foram convidados a participar os mesmos quatro principais candidatos, sendo que nesse momento, a um mês da realização das eleições do primeiro turno, a diferença entre o segundo colocado, Ciro Gomes, e o terceiro, José Serra, já havia diminuído, com a quase estagnação de Lula em primeiro e Garotinho em quarto ${ }^{8}$.

O mediador foi o jornalista Boris Casoy, experiente na função exercida em debates anteriores. Os candidatos estavam dispostos da esquerda para a direita com Garotinho, Lula, Serra e Ciro bem próximos em suas posições, o que facilitava, mesmo com microfones isolados e cortados, manifestações fora do tempo usando o microfone alheio como canal. Aqui a estrutura normativa foi apresentada e explicada pelo próprio mediador, que acaba por personificar as regras - ponto, em certa medida, desregulamentador do debate, uma vez que o tornou juiz da interação claramente visível e interpelável pelos agentes, ao contrário do debate anterior, no qual os juízes não estavam acessíveis e apenas comunicavam à mediadora suas decisões. Estabeleceu-se a possibilidade implícita de questionamento da estrutura normativa, principalmente nos momentos de acirramento do conflito quando são julgados os direitos de resposta. Isto irá configurar um momento interessante de barganha no debate.

Temos de novo uma interação entre Ciro e Serra - controlada com mais dificuldade por Boris Casoy -, quando Serra mesmo alertado sobre o término do seu tempo continua a falar. Nesse momento da campanha, as acusações contra Ciro estão dando certo de acordo com as pesquisas e Serra mantém a estratégia de desclassificar moralmente o oponente. Ciro também tenta partir para o campo moral desafiando Serra a assumir ali as críticas veiculadas na TV. O ponto interessante a 
ser notado é que, ao fazer isso, Ciro aceitava manter o debate no campo e no enquadramento que Serra havia originalmente proposto desde o debate anterior, o que só poderia resultar em ganhos para o adversário. Vejamos o contraste (Exemplo 5):

\begin{tabular}{|c|c|}
\hline $\begin{array}{l}\text { Ciro } \\
\text { (pergunta) }\end{array}$ & $\begin{array}{l}\text { Como eu não posso fazer a mim mesmo, eu vou fazer ao candidato do } \\
\text { governo, José Serra. Serra, você tem feito com milhões de reais uma } \\
\text { campanha sórdida de agressões a mim, sem assinatura, "Ciro, mudan- } \\
\text { ça ou problema". O sr. tem agora uma ocasião de na minha presença } \\
\text { fazer o ataque que o sr. me fez de forma clandestina, embora não tenha } \\
\text { nunca ofendido a minha honra nem atacado a minha honestidade, } \\
\text { mas tentado fazer parecer à população que eu sou algum tipo de des- } \\
\text { temperado ou de desequilibrado que não teria a serenidade necessá- } \\
\text { ria para governar o Brasil. Mas a pergunta que eu quero fazer é... }\end{array}$ \\
\hline Boris & Tempo candidato... \\
\hline $\begin{array}{l}\text { Ciro } \\
\text { (continuação } \\
\text { da pergunta) }\end{array}$ & $\begin{array}{l}\text { Os senhores produziram } 11 \text { milhões e } 700 \text { mil desempregados, por } \\
\text { que um brasileiro deve acreditar que o sr. vai produzir } 8 \text { milhões de } \\
\text { empregos em } 4 \text { anos? }\end{array}$ \\
\hline Boris & 2 min. para a resposta do candidato José Serra. \\
\hline $\begin{array}{l}\text { Serra } \\
\text { (resposta) }\end{array}$ & $\begin{array}{l}\text { O brasileiro deve acreditar e vai acreditar, primeiro porque eu não tô } \\
\text { prometendo, eu vou mostrar como isso é possível, Ciro, eu tenho pre- } \\
\text { paro pra isso e tenho coerência, nós não estamos fazendo nenhuma } \\
\text { campanha sórdida, nós estamos mostrando o que você diz, se o Bra- } \\
\text { sil aprendeu duas coisas nessa campanha: primeiro foi que a maior } \\
\text { parte das coisas que você disse são mentira, como que tinha pago } 100 \\
\text { dólares de salário-mínimo, como que tinha pago toda a dívida mobi- } \\
\text { liária do Ceará, enfim, um conjunto de mentiras e a cada dia aparece; } \\
\text { em segundo lugar, que você é especialista em fazer acusações que } \\
\text { você não comprova, tanto é assim que o Tribunal Eleitoral nos deu a } \\
\text { nós direito de resposta uma vez e hoje novamente de novo, porque o } \\
\text { seu programa disse coisas ilegais que não podem ser contestadas, e } \\
\text { nós não, portanto se alguém está transgredindo e fazendo campanha } \\
\text { sórdida é você e a sua campanha, nós não temos responsabilidade } \\
\text { pelas coisas que você diz, se você chama um aliado seu como o ACM } \\
\text { de "mais sujo que pau de galinheiro", e ainda mente quando diz que } \\
\text { depois se reconciliou com ele mas na verdade falou isso um ano de- } \\
\text { pois, se você chama um outro aliado seu como o Fleury de "aborto da } \\
\text { natureza" isso quem disse foi você, cê chama um ouvinte de burro foi } \\
\text { você quem disse, nós não estamos inventando e se alguém que é es- } \\
\text { pecialista na vida pública em insultar, que chamou o presidente da } \\
\text { República de "ameba", que chamou o ACM de "mais sujo que pau de } \\
\text { galinheiro", o Fleury de "aborto da natureza", os consumidores de } \\
\text { "otários", os empresários disso e daquilo, foi você e quem é presi- } \\
\text { dente da República tem que tomar muito cuidado entre o que diz e } \\
\text { aquilo que faz, que é o problema da mentira; e segundo de fazer acu- } \\
\text { sações falsas, acusações que não podem ser comprovadas. }\end{array}$ \\
\hline
\end{tabular}




\begin{tabular}{|c|c|}
\hline Boris & O candidato Ciro Gomes tem agora $1 \mathrm{~min}$. para a sua réplica. \\
\hline $\begin{array}{l}\text { Ciro } \\
\text { (réplica) }\end{array}$ & $\begin{array}{l}\text { Eu tenho pedido a Deus pra me dar luz e serenidade e na verdade eu } \\
\text { devo desculpas ao povo brasileiro, porque fui inocente quando não } \\
\text { me acautelei de estar sendo seguido com os telefones grampeados } \\
\text { por equipes do sr. José Serra, com câmeras de televisão e naquele de- } \\
\text { bate da Bahia, no rádio, na mesma hora eu pedi desculpas, porque fui } \\
\text { agredido e insultado, mas ele cortou, editou e mais, você brasileiro } \\
\text { está vendo, ninguém assinou, ele não assumiu responsabilidade ne- } \\
\text { nhuma e eu tenho absolutamente condição de demonstrar que: pri- } \\
\text { meiro, o salário-mínimo de } 82 \text { dólares a } 10 \text { anos atrás significa } 99 \text { dó- } \\
\text { lares e } 50 \text { centavos hoje; as lutas que eu tive, não só com o Antônio } \\
\text { Carlos, mas com o sr. também, são lutas de um homem que tem com- } \\
\text { batido a corrupção, a ladroeira, a promessa mentirosa, ao longo dos } \\
\text { últimos } 20 \text { anos e o sr. trabalhou comigo durante } 8 \text { anos no meu parti- } \\
\text { do que era o mesmo seu, o PSDB, e nunca disse isso na minha frente e } \\
\text { hoje se utiliza desses expedientes sem assinar porque é aquilo que } \\
\text { todo brasileiro já sabe: um homem que faz da rasteira e de tirar o ta- } \\
\text { pete dos seus adversários a forma de fazer política. }\end{array}$ \\
\hline Boris & 1 min. para a tréplica do candidato José Serra. \\
\hline $\begin{array}{l}\text { Serra } \\
\text { (tréplica) }\end{array}$ & $\begin{array}{l}\text { Taí a mania de fazer acusações sem provar, porque todos os filmes es- } \\
\text { tão assinados, aliás o Tribunal Eleitoral pode dar o testemunho disso, } \\
\text { e os seus filmes fazendo ataques estão assinados de maneira até mais } \\
\text { tímida, menor, do que nós temos feito, portanto tudo está com assi- } \\
\text { natura, veja a mania de querer distorcer as coisas... }\end{array}$ \\
\hline $\begin{array}{l}\text { Ciro } \\
\text { (intromissão) }\end{array}$ & (inaudível) \\
\hline $\begin{array}{l}\text { Serra } \\
\text { (continuação } \\
\text { da tréplica) }\end{array}$ & $\begin{array}{l}\text { [...] a questão do fotógrafo ou do cinegrafista do Ciro Gomes acusou } \\
\text { e que era do PT, insultou o sujeito dizendo: "você trabalha para o Ser- } \\
\text { ra", depois o país inteiro ficou sabendo que o rapaz era do PT. Essa } \\
\text { questão da Bahia que foi filmada, você chamando de "burro" um ou- } \\
\text { vinte, um teles..., um ouvinte que fazia uma pergunta [...] }\end{array}$ \\
\hline $\begin{array}{l}\text { Ciro } \\
\text { (intromissão) }\end{array}$ & (inaudível) \\
\hline $\begin{array}{l}\text { Serra } \\
\text { (continuação } \\
\text { da tréplica) }\end{array}$ & $\begin{array}{l}\text { [...] essa pergunta feita, ela foi filmada e sem microcâmera, não foi es- } \\
\text { sas microcâmeras que as televisões usam, era uma filmagem que es- } \\
\text { tava se fazendo normalmente e que chegou as nossas mãos, não era } \\
\text { mas podia ter sido do PSDB, da mesma maneira que o PT mandou fil- } \\
\text { mar você cometendo uma ilegalidade, do ponto de vista de utilizar } \\
\text { um serviço [...], um esquema público na tele [...], como campanha } \\
\text { eleitoral, agora por outro lado eu quero dizer o seguinte [...] }\end{array}$ \\
\hline Boris & Seu tempo terminou candidato Serra! \\
\hline $\begin{array}{l}\text { Serra } \\
\text { (contir } \\
\text { da trép }\end{array}$ & {$[\ldots]$ essa mania, essa mania de acusar sem comprovações $[\ldots]$} \\
\hline
\end{tabular}




\begin{tabular}{ll}
\hline Boris & Serra, o seu tempo terminou! \\
\hline $\begin{array}{l}\text { Serra } \\
\text { (continuação }\end{array}$ & {$[\ldots]$ o Ciro tanto tem que ele foi condenado em primeira e segunda } \\
da tréplica) & \\
\hline Boris & Candidatiça o seu tempo terminou! \\
\hline $\begin{array}{l}\text { Serra } \\
\text { (continuação }\end{array}$ & {$[\ldots .$.$] por acusações indevidas ao Henrique Santilo.$} \\
da tréplica) & \\
\hline
\end{tabular}

Na próxima seqüência podemos perceber um momento em que o mediador perde o controle do debate ao ser pressionado. Quanto mais personalizada é a ordem normativa tanto maior a possibilidade de negociá-la em claro contraste com o modelo impessoal do debate anterior (Exemplo 6):

\begin{tabular}{|c|c|}
\hline $\begin{array}{l}\text { Ciro } \\
\text { (tréplica) }\end{array}$ & $\begin{array}{l}\text { As privatizações que foram prometidas como uma fórmula de resolver } \\
\text { o problema da dívida simplesmente aconteceram, se apuraram bilhões } \\
\text { de dólares nas privatizações e a dívida brasileira, consolidada dívida } \\
\text { interna do setor público saiu de } 153 \text { pra } 860 \text { bilhões de reais, o funciona- } \\
\text { lismo público } 8 \text { anos sem reajuste, as estradas destruídas, os caminho- } \\
\text { neiros do Brasil sabem do que eu estou falando, perdemos um boa par- } \\
\text { te dos mestres e doutores das universidades públicas, os aposentados } \\
\text { estão humilhados, } 13 \text { milhões ganhando uma aposentadoria que não } \\
\text { paga duas caixas de remédio pra hipertensão, a gente pergunta pra } \\
\text { onde foi essa montanha de dinheiro pro candidato do governo, ele não } \\
\text { responde, o meu vice perguntou pra vice dele, ela também não respon- } \\
\text { deu, e o mais grave todas as tarifas explodiram, energia elétrica, telefo- } \\
\text { ne, energia e energia um escândalo, o apagão obrigou as pessoas a raci- } \\
\text { onarem e o governo está obrigando as pessoas a pagarem a energia que } \\
\text { não foi vendida, essa é a privatização: lucro privado, prejuízo espetado } \\
\text { nas costas do povo trabalhador brasileiro. }\end{array}$ \\
\hline Serra & (inaudível - pedindo questão de ordem) \\
\hline Boris & $\begin{array}{l}\text { Não há questão de ordem agora candidato Serra, porque o governo vai } \\
\text { ser mencionado o tempo todo... }\end{array}$ \\
\hline Serra & Mas eu fui mencionado pessoalmente. \\
\hline Boris & $\begin{array}{l}\text { Não o senhor foi mencionado pessoalmente mas é uma crítica de cará- } \\
\text { ter administrativo... }\end{array}$ \\
\hline Serra & $\begin{array}{l}\text { (inaudível) Quando as críticas são feitas a mim diretamente (inaudí- } \\
\text { vel)... }\end{array}$ \\
\hline Boris & Sim, não, mas isso, as regras são essas, eu não... \\
\hline Serra & (inaudível) a oportunidade de explicar... \\
\hline Boris & Agora, o sr. terá a oportunidade dentro do seu tempo... \\
\hline
\end{tabular}


A Retórica como Modelo Analítico da Racionalidade Instrumental...

\begin{tabular}{|c|c|}
\hline Serra & Mas o meu tempo... \\
\hline Boris & O sr. não está sendo ofendido, nós... \\
\hline Serra & Boris, veja bem, o meu tempo é usado para responder as perguntas... \\
\hline Boris & $\begin{array}{l}\text { Sim, mas o que, a decisão, candidato Serra, é que o direito de resposta } \\
\text { seria dado as ofensas de caráter pessoal, nós não podemos permitir que } \\
\text { essas respostas a cada ataque do governo sejam, ao governo sejam fei- } \\
\text { tas agora... }\end{array}$ \\
\hline Lula & (inaudível - reivindicando a palavra) \\
\hline Boris & Sim, Lula. \\
\hline Garotinho & (inaudível) \\
\hline Boris & Não, mas o... \\
\hline Lula & Eu quero fazer uma ressalva... \\
\hline Boris & Sim, pode fazer a ressalva. \\
\hline Lula & $\begin{array}{l}\text { Serra disse que tem uma tabelinha, não tem tabelinha, eu tenho per- } \\
\text { guntas, eu tenho que fazer pergunta para cada um, eu vou fazer per- } \\
\text { gunta pra você (Serra)... }\end{array}$ \\
\hline Boris & Sim, mas se houver tabelinha \\
\hline Lula & [...] você tem o ônus de ser do governo, tem o ônus de ser do governo. \\
\hline Boris & Nós não vamos agora fazer um debate sobre essa questão... \\
\hline Serra & (inaudível) \\
\hline Boris & $\begin{array}{l}\text { Candidato Serra, por gentileza vamos continuar o debate! O candidato } \\
\text { Ciro Gomes escolhe quem responde e faz a sua pergunta em } 30 \text { seg. }\end{array}$ \\
\hline
\end{tabular}

Ao ser mencionado o processo de privatizações - em uma interação que tem início em uma pergunta de Lula para Ciro - Serra intervém reivindicando um aparte que é debatido por todos até o ponto em que o mediador - sem o controle da palavra - dá a voz a Lula que aproveita para atacar - fora do tempo - Serra (àquela altura muito provavelmente o seu oponente no segundo turno), enquadrando-o no tópico que seria recorrente doravante: Serra era governo, portanto responsável por todos os problemas que o eleitor via na administração FHC. Em "[...] você tem o ônus de ser do governo, tem o ônus de ser do governo" temos o entimema implícito [se não FHC/Serra, então Lula].

A fragilidade da estrutura normativa deste debate, que estava centrada no julgamento subjetivo do próprio mediador, presente e passível de contestação, é acentuada. Na próxima seqüência, Boris Casoy dialoga com os candidatos - todos de microfone cortado cedendo -, ao candidato Garotinho que o pressionava. Na passagem abaixo transparece como a estrutura normativa se confunde com a presença do 
mediador, contribuindo para vários momentos de conflito desregrado durante o debate, que o tornou bem mais saboroso do ponto de vista do espetáculo (Exemplo 7).

\begin{tabular}{ll}
\hline Boris & $\begin{array}{l}\text { Eu vou conceder também, benevolente que eu estou hoje, eu vou con- } \\
\text { ceder ao sr. (Garotinho) também o direito de de res [...] }\end{array}$ \\
\hline Serra & Inaudível \\
\hline Boris & $\begin{array}{l}\text { Não há desigualdade candidato Serra, e neste momento eu sinto que } \\
\text { eu devo conceder a ele o direito de resposta [...] }\end{array}$ \\
\hline Serra & Inaudível \\
\hline Boris & $\begin{array}{l}\text { Eu quero esclarecer aos senhores candidatos que eu tendo alguma dú- } \\
\text { vida eu prefiro conceder o direito de resposta [...] }\end{array}$ \\
\hline Serra/Lula & \begin{tabular}{l} 
Inaudível \\
\hline Boris
\end{tabular} \\
$\begin{array}{l}\text { Eu quero contar aos senhores telespectadores que isso me foi delegado } \\
\text { porque os assessores dos candidatos se reuniram e discutiram, discuti- } \\
\text { ram, discutiram pra definir ofensa, não conseguiram, alguém então } \\
\text { teve a brilhante idéia de dizer olha: o Boris sabe bem o que é e ele resol- } \\
\text { ve, e eu estou resolvendo a minha maneira, democraticamente afinal } \\
{[\ldots] \text { por favor não votem em mim [...] }}\end{array}$ \\
\hline
\end{tabular}

Ao olhar para as câmeras e invocar os telespectadores, Boris Casoy quis exatamente lembrar aos candidatos que havia um público supostamente esperando certa ordem no debate. O expediente foi eficaz e o mediador justificou-se atribuindo sua centralidade na situação a uma delegação feita pelos assessores dos candidatos, o que permitia concluir que a responsabilidade pela ordem precária não era sua. O sentido do movimento operado pelo agente é, mais uma vez, plausivelmente deduzido da relação entre a sua retórica e o contexto da ação.

\section{DISCUSSÃO}

As conseqüências do modelo analítico concebido são significativas para o debate sobre ação e racionalidade. No campo metodológico, acentua-se a plausibilidade de uma posição microssociológica e empirista para a reflexão desses pontos, tradicionalmente pensados em termos de teoria pura e formalizações. Trata de se avaliar tais leituras e de reconfigurá-las, usando dados que indicam um caminho preponderantemente descritivo para investigar as operações racionais. $\mathrm{O}$ paradigma lingüístico traz a necessidade de enquadrar os processos de ação em relações interativas, como base elementar para compreendermos qual é a arquitetura da intersubjetividade com a qual as estru- 
turas normativas podem coesivamente estabilizar a ordem, ao mesmo tempo que são recursos de ação assimetricamente jogados em campo (Garfinkel e Sacks,1986; Zimmerman e Boden, 1991; Schegloff, 1991).

A retórica vem responder ao projeto de uma teoria lingüística da racionalidade instrumental, no qual a influência (intencionalidade em persuadir e ser persuadido) é condição necessária do consenso e do trato com o conflito. Se a opção pelo foco na linguagem se justifica em argumentos metodológicos, não será absurdo dizer, quase por oposição, que, ontologicamente, a retomada do conceito de retórica reconduz à teoria política um saber que está em suas origens e em momentos cruciais de sua consolidação. O instrumento do animal político é a palavra e ela é a um só tempo manifestação e recurso de sua prudência prática (phronesis) na edificação da pólis. A adesão ao campo da linguagem (longe de significar a postulação de uma nova racionalidade comunicativa) é - ao contrário - o lugar de se pensar a estrutura teleológica dos atos e suas razões (quer afetivas, quer calculativas).

Por outro lado, a investigação sobre a linguagem não pode ser reduzida a pensar indivíduos, por supor que estes sejam sempre concebidos como agentes constituídos em relações que preferimos estudar como interações. Isso altera decididamente a leitura do movimento racional, mesmo calculativo, como um processo centrado na mente maximizadora do ator. A escolha racional é uma vertente teórica, cujo ponto mais frágil reside na não-problematização do seu conceito operatório básico: a idéia de informação. Nessa teoria, o agente coleta evidências dos fatos e o único problema é o custo de sua obtenção, dando como suposto da racionalidade que as informações juntadas traduzem um quadro verossímil da realidade. Ao contrário, as informações que sustentam os dados disponíveis para o campo cognitivo do agente são retóricas: são dados organizados em tópicos, cuja aceitação aciona um enquadramento e um conjunto provável de argumentos. A organização do discurso dos agentes racionais, mesmo em situações de mercado, é assentada em operações entimêmicas intersubjetivas. A imaginada máquina de maximizar utilidades nada mais é que um agente sendo persuadido a agir baseado apenas em possibilidades de deliberação feitas de palavras e, vale enfatizar, muito falíveis. Talvez o maior impacto que tais proposições tenham para a escolha racional seja realmente a possibilidade de, por meio da retórica, retirarmos a teoria da ação instrumental do individualismo que nela im- 
pera: uma vez que argumentos são sempre apropriações de tópicos socialmente construídos e somente operam em redes de sentido impossíveis de serem reduzidas à subjetividade dos agentes interessados.

Ao colocar o jogo semilógico em evidência, o modelo retórico quer retomar certas possibilidades analíticas da formalização esquemática para descrever os usos operatórios da argumentação. O apuro descritivo tem a pretensão não apenas de captar o conteúdo dos argumentos, mas, sobretudo, sua arquitetura recorrente. Os entimemas são a chave para compreendermos o movimento e a lógica da "razão mundana" (Pollner, 1987), que orienta políticos, consumidores, intelectuais, policiais ou qualquer outro ator. Essa é a mesma "lógica" do eleitor/cidadão, sustentando todos os debates públicos contra qualquer quimera de um encontro grandioso da democracia com deliberações criticamente fundadas.

Os temas aqui tratados se têm, por razões operacionais de um programa de pesquisa, concentrado nos aspectos lógicos da retórica, um alcance limitado para um tratamento geral da noção de persuasão. Questões relativas aos universos morais e afetivos das interações retóricas foram aqui apenas tangenciadas e reclamam atenção. Em um momento em que parece haver na academia brasileira a tendência de enfatizar aspectos não racionais da agregação - a democracia como crença ou religião civil -, é necessário que haja um olhar detido na relação dos discursos com os valores lançados em campo.

Argumenta-se hoje em dia que é perceptível o crescimento contínuo de uma judicialização da cidadania e da política (Werneck Vianna, 2002; Eisenberg, 2002), no qual agentes comuns têm o seu poder de conformar o mundo ampliado ao acionarem regras jurídicas, que regulam direitos cada vez mais generalizadamente compartilhados e procedimentos judiciais passam a ter vigência na rotina do poder (Comissões Parlamentares de Inquérito e similares). Pode-se concluir daí que existe precisamente a ampliação dos espaços por excelência da retórica: no mundo "judicializado" as regras existem quando são acionadas discursivamente e confrontadas com outras interpretações persuasivas delas mesmas. Acreditamos que a análise da criação da persuasão nesses contextos é a chave para a satisfação das exigências empíricas para se discutir a direção dessa judicialização. Mesmo porque, se certo ramo pragmatista do pensamento jurídico - como afir- 
mou José Eisenberg (2002:8) - rejeita a metafísica do direito, quer avaliar as conseqüências de aparatos legais para julgar sua validade e deseja vincular projetos éticos a necessidades sociais, é boa prática remontar aos agentes, e estes são em larga medida produtores de retóricas que causam fatos e deliberações e, dessa forma, a face real do direito, ou seja, da ordem normativa legal. A funcionalidade das deliberações é diretamente relacionada à habilidade que os agentes têm de persuadir livremente a todos e a si mesmos, munidos com meras opiniões, uma vez que nenhuma ação política ou jurídica resiste à paralisia da dúvida metódica.

(Recebido para publicação em julho de 2003) (Versão definitiva em junho de 2004)

\section{NOTAS}

1. Normalmente estamos tratando, nesse caso, de certa tradição da ciência política, na qual atores disputam metas excludentes, ou seja, o ganho de um implica a perda do outro. Mais especificamente, entende-se aí por razão instrumental a disposição, mais ou menos complexa, de visualizar e articular meios supostamente eficientes para atingir fins postos pelo agente e, por estratégia, nesse contexto, certas habilidades de um agente em jogar com o comportamento dos outros envolvidos no campo da ação, levando em consideração seus movimentos, atuais ou previsíveis, como dados ou componentes para a atualização, ou correção, de suas próprias ações em um momento seguinte. Essa versão clássica da racionalidade instrumental tem pontos de aproximação com a tradição utilitarista, sendo apropriada e trabalhada por esta, com grande influência, por meio do que chamaremos de modelos computacionais do ator, nos quais há grande ênfase nos aspectos relativos à obtenção e interpretação subjetiva das informações que levam à decisão $X$ ou Y (por exemplo, Downs, 1957; Elster, 1984). O agente calculador/maximizador é o conceito-chave da tradição econômica, cuja única concessão aos críticos foi o reconhecimento de grandes limites à capacidade de processamento dos agentes. Essencialmente, os trabalhos de Herbert Simon estabeleceram que o comportamento racional é antes de tudo "adaptativo", ou seja, em vez de tentar sempre a melhor decisão, procura adaptar-se às circunstâncias (Simon, 1967; Kaneman e Tversky, 1986; March, 1986). Estudos empíricos e teóricos da própria linhagem da escolha racional, aplicados aos macroproblemas de decisão política, como o voto, indicaram que os agentes tendem a decidir suas escolhas com base em informações imperfeitas, e não por meio de informações ótimas (Popkin, 1991; Lupia e McCubbins, 1998; Figueiredo, 1998). 
2. As críticas da sociologia normativa (por exemplo, Parsons, 1968) ao modelo econômico de ação sempre sublinharam o irrealismo de se tentar descrever o comportamento racional dos agentes empíricos usando uma analogia computacional. O argumento parsoniano era de que nenhuma ordem dependente apenas do interesse utilitário dos agentes tem o devido equilíbrio e estabilidade na ausência de um corpo normativo, que coordena e valida os cursos de ação. Mudanças significativas na crítica da racionalidade ocorreram com o chamado paradigma da linguagem. Dentre as suas manifestações existe a microssociologia fenomenológica. Essa perspectiva analítica propõe que decisões racionais são construídas pelo entendimento intersubjetivo em processos de linguagem (Garfinkel e Sacks (1986) [1969]). Se o modelo computacional da escolha racional se assentava na analogia entre processos subjetivos e uma máquina de calcular, o paradigma da linguagem trouxe aos modos de agir uma leitura fortemente descritiva, na medida em que seres reais usam linguagens para a elaboração de seus planos de ação, e só podem refletir de forma complexa sobre eles, valendo-se de procedimentos de linguagem. Estes, mais do que qualquer conceito de consciência, são passíveis de análise para se discutir o sentido do ato. A partir do campo da linguagem tem-se um espaço empírico para tratar a racionalidade, uma proposição que ficará mais conhecida pela influente formulação de Habermas (1989; 1990), com sua teoria da ação comunicativa.

3. Os dados do Procon - JF fazem parte da pesquisa Interações de Fala em Situações de Conflito, já mencionada. A base de dados dispõe de dezesseis audiências de conciliação (acareações) do Procon e duas sessões do Tribunal de Pequenas Causas. Os demais dados aqui usados, relativos aos debates televisivos, fazem parte da pesquisa A Retórica como Modelo Analítico da Racionalidade Instrumental.

4. A seção teórica deste trabalho consiste essencialmente na reelaboração de parte do capítulo 3 da tese Racionalidade e Retórica: Teoria Discursiva da Ação Coletiva, já referida como matriz dessa investigação.

5. A retórica, conforme Aristóteles, possui três gêneros: deliberativo, judiciário e epidíctico. No modelo elaborado em Magalhães (2000), é proposto um quarto modo, o analítico, para contemplar a análise dos usos persuasivos de argumentos técnicos e científicos.

6. A noção de figuração aqui é diretamente inspirada na noção de figuração lógica de Wittgenstein. O conceito wittgensteiniano de "figuração lógica" - apresentado no Tractatus Logico-philosophicus - refere-se exatamente à relação entre a disposição dos elementos nas proposições lógicas elementares e a disposição dos elementos nos fatos que constituem a realidade. A concepção de Wittgenstein é de um mundo que só pode ser pensado a partir dos fatos que estabelecemos sobre as coisas e não a partir das próprias coisas. Estas são inexprimíveis em seu sentido, mas são mostráveis por meio da linguagem que produz os fatos. O conceito de figuração lógica é exatamente a designação da possibilidade de a linguagem mostrar a estrutura lógica dos objetos, figurá-los como fatos. Fica clara uma relação entre os aforismos: 2.11 "Figuramos os fatos" e 2.141 "A figuração é um fato", ou seja, as operações do pensamento por meio da linguagem criam fatos para estabelecer fatos. Considerando os aforismos 2.12 "A figuração é um modelo da realidade" e 2.15 "Que os elementos da figuração estejam uns para os outros de uma determinada maneira representa que as coisas assim estão umas para as outras. Essa vinculação dos elementos da figuração chama-se sua es- 
trutura; a possibilidade desta, sua forma de afiguração" (ênfases nossas), ambos indicam que a noção de figuração é tanto de "representação" quanto de "estrutura lógica" (Wittgenstein, 1994:143-147). Para discutir esse tema com consideráveis divergências, ver Ricketts, 1996; Toulmin e Janik, 1991; Hintikka e Hintikka, 1994; Russell, 1994.

7. A pesquisa do Instituto Brasileiro de Opinião Pública e Estatística - IBOPE realizada entre 27 e 29 de julho (5 dias antes do debate), apontava Lula com 34\%, Ciro 25\%, Serra $14 \%$, Garotinho $11 \%$, brancos e nulos $5 \%$, indecisos $10 \%$, outros $1 \%$.

8. A pesquisa do IBOPE realizada entre 31 de agosto e 2 de novembro (terminando no dia do debate), apontava Lula com 35\%, Ciro 17\%, Serra 17\%, Garotinho $11 \%$, brancos e nulos $5 \%$, indecisos $14 \%$, outros $1 \%$.

\section{REFERÊNCIAS BIBLIOGRÁFICAS}

ARISTÓTELES. (1978), Tópicos. São Paulo, Abril Cultural (Col. Os Pensadores). (1988), The Rhetoric of Aristotle. Englewood Cliffs, Prentice-Hall.

BARILLI, Renato. (1985), Retórica. Lisboa, Presença.

BOUDON, Raymond. (1989), A Ideologia, ou a Origem das Idéias Recebidas. São Paulo, Ática.

(1990), L'Art de se Persuader des Idées Fausses, Fragiles ou Douteses. Paris, Fayard.

DOWNS, Anthony. (1957), An Economic Theory of Democracy. New York, Harper \& Row.

EISENBERG, José. (2002), “Pragmatismo, Direito Reflexivo e Judicialização da Política", in L. Werneck Vianna (org.), A Democracia e os Três Poderes no Brasil. Belo Horizonte, Editora da UFMG.

ELSTER, Jon. (1984), Ulisses and the Sirens. Studies in Rationality and Irrationality. Cambridge, Cambridge University Press.

FIGUEIREDO, Marcus F. et alii. (1998), “Estratégias de Persuasão em Eleições Majoritárias: Uma Proposta Metodológica para o Estudo da Propaganda Eleitoral". Série Estudos, no 100 . Rio de Janeiro, IUPERJ.

GARFINKEL, Harold e SACKS, Harvey. (1986) [1969]. “On Formal Structures of Practical Actions", in H. Garfinkel (org.), Ethnomethodological Studies of Work. London/New York, Routledge \& Kegan Paul.

HABERMAS, Jürgen. (1989), Théorie de L'Agir Communicationnel. Paris, Fayard, vols. I e II.

(1990), Pensamento Pós-Metafísico. Rio de Janeiro, Tempo Brasileiro.

HINTIKKA, Merril B. e HINTIKKA, Jaakko. (1994), Uma investigação sobre Wittgenstein. Campinas, Papirus. 
KANEMAN, Daniel e TVERSKY, Amos. (1986), The Framing of Decisions and the Psychology of Choice, in J. Elster (org.), Rational Choice. New York, New York University Press.

LEWIS, David. (1986), On Plurality of Worlds. Oxford, Basil Blackwell.

LUPIA, Arthur e McCUBBINS, Mathew. (1998), The Democratic Dilemma, Can Citizens Learn what They Need to Know? Cambridge, Cambridge University Press.

MAGALHÃES, Raul F. (1997), “Ciência, Ficção e Contrafactualidade, Aproximações Exploratórias". Série Estudos, no 98. Rio de Janeiro, IUPERJ.

. (2000), Racionalidade e Retórica: Teoria Discursiva da Ação Coletiva. Tese de Doutorado. Rio de Janeiro, IUPERJ.

MARCH, James G. (1986), “Bounded Rationality, Ambiguity, and the Engineering of Choice", in J. Elster (org.), Rational Choice. New York, New York University Press.

MEYER, Michel. (1994), “As Bases da Retórica”, in M. M. Carrilho (org.), Retórica e Comunicação. Porto, Edições Asa.

. (1998), Questões de Retórica, Linguagem, Razão e Sedução. Lisboa, Edições 70.

OSAKABE, Haquira. (1979), Argumentação e Discurso Político. São Paulo, Kairós.

PARSONS, Talcott. (1968), The Structure of Social Action. New York, The Free Press.

PEÇANHA, José A. Motta. (1989), "Teoria da Argumentação ou a Nova Retórica", in Paradigmas Filosóficos da Atualidade. Campinas, Papirus.

PERELMAN, Chaïm. (1997), Retóricas. São Paulo, Martins Fontes.

_ e OLBRECHTS-TYTECA, Lucie. (1996), Tratado da Argumentação, a Nova Retórica. São Paulo, Martins Fontes.

POLLNER, Melvin. (1987), Mundane Reason, Reality in Everyday and Sociological Discourse. Cambridge, Cambridge University Press.

POPKIN, Samuel L. (1991), The Reasoning Voter. Chicago, Chicago University Press.

RAPOPORT, Anatol. (1980), Lutas, Jogos e Debates. Brasília, UnB.

REBOUL, Olivier. (1998), Introdução à Retórica. São Paulo, Martins Fontes.

REIS, Fábio W. (1984), “Política e Racionalidade, Problemas de Teoria e Método de uma Sociologia Crítica da Política". Revista Brasileira de Estudos Políticos. Belo Horizonte, UFMG/PROED.

RICKETTS, Thomas. (1996), "Pictures, Logic, and the Limits of Sense in Wittgenstein's Tractatus", in H. Sluga e D. Stern (orgs.), The Cambridge Companion to Wittgenstein. Cambridge, Cambridge University Press.

ROHDEN, Luiz. (1997), O Poder da Linguagem, a "Arte Retórica" de Aristóteles. Porto Alegre, EDIPUCRS.

RONEN, Ruth. (1994), Possible Worlds in Literary Theory. Cambridge, Cambridge University Press.

RUSSELL, Bertrand. (1994), "Introdução", in L. Wittgenstein, Tractatus Logico-philosophicus. São Paulo, EDUsP. 
SCHEGLOFF, Emanuel. (1991), "Reflections on Talk and Social Structure", in D. H. Zimmerman e D. Boden, Talk and Social Structure, Studies in Ethnomethodology and Conversation Analysis. Berkeley/Los Angeles, University of California Press.

. (1996), Turn Organization: One Intersection of Grammar. Cambridge, Cambridge University Press.

SCHUTZ, Alfred. (1974), "El Problema de la Racionalidad en el Mundo Social”, in Estudios sobre Teoría Social. Buenos Aires, Amorrortu Editores.

e LUCKMANN, Thomas. (1977), Las Estruturas del Mundo de la Vida. Buenos Aires, Amorrortu.

SIMON, Herbert. (1967), Models of Man, Social and Rational. New York, John Wiley \& Sons.

TOULMIN, Stephen.(1994), “Racionalidade e Razoabilidade”, in M. M. Carrilho (org.), Retórica e Comunicação. Porto, Edições Asa. . (1997), The Uses of Argument. Cambridge, Cambridge University Press. e JANIK, Allan. (1991), A Viena de Wittgenstein. Rio de Janeiro, Ed. Campus.

WEBER, Max. (1991), “Conceitos Sociológicos Fundamentais.”, Economia e Sociedade. Brasília, UnB, vol. 1.

WERNECK VIANNA Luiz. (2002), “Revolução Processual do Direito e Democracia Progressiva", in L. Werneck Vianna (org.), A Democracia e os Três Poderes no Brasil. Belo Horizonte, Editora da UFMG.

WITTGENSTEIN, Ludwig. (1994), Tractatus Logico-philosophicus. São Paulo, EduSP.

ZIMMERMAN, Don H. e BODEN, Deirdre. (1991), “Sctructure in Action: An Introduction", in Talk and Social Structure, Studies in Ethnomethodology and Conversation Analysis. Berkeley/Los Angeles, University of California Press. 


\section{ABSTRACT \\ Rhetoric as an Analytical Model of Instrumental Reason: Theoretical and Empirical Approaches}

This article makes a theoretical reconstruction of a model for instrumental reason in language, using the notion of rhetoric. It takes persuasive language to be constitutive of instrumental reason, and analyses the possibility of pictorial representation of the operation of reason by sketching out the quasi-logical components of arguments made by actors in strategic discursive interaction, in cases collected from empirical contexts of the conflictive use of speech. The article closes with reflections on the consequences of its proposals for the theory of instrumental reason, and affirms that rhetoric is the place par excellence for political theory to operate the connection between molded intersubjective rationality and strategic action.

Key words: political rhetoric; instrumental reason; strategy of persuasion

\section{RÉSUMÉ}

La Rhétorique comme Modèle Analytique de la Rationalité Instrumentale: Démarches Théoriques et Empiriques

Dans cet article, on travaille la reconstruction théorique d'un modèle de rationalité instrumentale dans le domaine du langage à partir de la notion de rhétorique. Considérant le langage de persuasion comme formateur de la raison instrumentale, on analyse la possibilité de représentation picturale de l'opération rationnelle à travers un schème de composantes quasi-logiques d'arguments lancés par les agents dans des interactions stratégiques du discours, prélevées dans le contexte empirique de l'usage conflictuel de la parole. En conclusion, on examine les conséquences éventuelles de ces propositions pour le domaine théorique de la discussion sur la rationalité instrumentale, tout en affirmant que la rhétorique est le lieu par excellence de la théorie politique quand elle veut effectuer les rapports entre une rationalité intersubjectivement façonnée et l'action stratégique.

Mots-clé: rhétorique politique; rationalité instrumentale; stratégie persuasive 